\title{
JUURNAL.RU
}

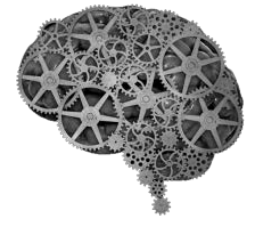

COMPANY GROUP "INTELLEKT"

\author{
Разяпова Л.М. \\ Городской суд г. Стерлитамака \\ Стерлитамак, Россия
}

doi: 10.18411/lj2016-7-2-12

idsp 000001: lj2016-16-2-12

\section{Участие переводчика на завершающем этапе судебного разбирательства в суде первой инстанции}

Постановление и оглашение приговора или иного судебного решения, завершающего рассмотрение уголовного дела в суде, не завершает деятельность судьи первой инстанции, который должен по окончании судебного разбирательства обеспечить сторонам возможность ознакомления с протоколом судебного заседания, по ходатайству сторон - предоставить возможность ознакомления с материалами уголовного дела. Судья должен рассмотреть вопросы, связанные с восстановлением пропущенного срока на подачу апелляционных жало, рассмотреть жалобы на протокол судебного заседания и выполнить иные действия, в соответствии с положениями УПК РФ. Таким образом, после оглашения судебного приговора (иного решения) суд первой инстанции переходит к завершающему этапу судебного разбирательства, который должен обеспечить защиту прав сторон в суде второй инстанции. Обеспечение возможности судебной защиты при обжаловании судебных решений осуществляется уже на завершающем этапе судебного разбирательства в суде первой инстанции. От качества выполнения судом полномочий на указанном этапе зависит и возможность своевременного обжалования и пересмотра судебного решения. 
Одной из процессуальных гарантий судебной защиты является предоставление лицу, не владеющему языком судопроизводства, участие переводчика. Законодатель не регламентирует основания и процессуальный порядок его предоставления. Проблема участия переводчика в уголовном судопроизводстве является одной из наиболее острых $[1$, с. 86-89; 2, с. 8-10; 3, с.209-212], поскольку в судах нет в штате переводчиков, кроме того очень часто нужны переводчики с малораспространенных языков, либо языков, которые не имеют письменности. Следует отметить, что судье, не владеющему языком, сложно определить качество перевода, кроме того отсутствуют юридические словари-переводчики с языков народов Российской Федерации на русский и наоборот, что вызывает сложность в оценке правильного толкования перевода конкретных понятий. Законодатель обязывает разъяснить право пользоваться родным языком или иным языком, которым владеет лицо, не владеющее или недостаточно владеющее языком судопроизводства. Соответственно, можно сделать вывод, что вопрос о предоставлении переводчика отдается на усмотрение самого лица, если оно недостаточно владеет языком судопроизводства, либо на усмотрение суда в случае, если лицо не владеет языком судопроизводства. Отсутствие четких критериев в понятии «не владеет» и «недостаточно владеет» может привести к принятию неправильного решения при удовлетворении или отказе в удовлетворении участия переводчика. Представляется, что в случае, если лицо пользовалось услугами переводчика при рассмотрении уголовного дела в судебном разбирательстве, то на завершающем этапе производства в суде первой инстанции ему в обязательном порядке должен быть представлен переводчик. Если лицо будет отказываться от переводчика на указанном этапе, то в последующем у него будет основание заявить о нарушении его права пользоваться услугами переводчика, что приведет к признанию нарушений в действии суда. В случае, если лицо не пользовалось услугами переводчика в суде первой инстанции, полагаем, что предоставление ему переводчика на завершающем этапе может иметь место 
только в случае заявлениям им ходатайства, разрешение которого отдается на усмотрение суда. Представляется, что удовлетворение данного ходатайства может иметь место в исключительных случаях, например, когда лицо заявить, что не может читать документы на государственном языке, прекрасно при этом владея устной речью. Признание «недостаточного владения» языком при отсутствии переводчика в судебном разбирательстве должно влечь за собой отмену принятого судебного решения.

Учитывая особенности профессиональной деятельности лиц, принимавших участие в качестве переводчиков по уголовному делу, представляется обоснованным мнение о необходимости «учитывать согласие лица, приглашаемого к участию в качестве переводчика» [1, с. 87]. Этот момент является очень важным, поскольку переводчик может быть приглашен из другого города, республики, государства, соответственно он не может находиться длительное время в другом городе, обеспечивая желание обвиняемого знакомиться с протоколом судебного заседания, либо с материалами уголовного дела неопределенное время. Учитывая, что переводчиков приглашают для участия в судебном процессе, и они не являются сотрудниками судебной системы, то обязать их неопределенное время оказывать помощь по переводу представляется невозможным.

Если переводчик, принимавший участие при производстве по уголовному делу не может присутствовать при ознакомлении с протоколом судебного заседания или повторно с материалами уголовного дела, то суд должен решить вопрос о замене переводчика.

Протокол судебного заседания отражает полностью процесс судебного разбирательства и является доказательством по уголовному делу, на основании которого вышестоящий суд может оценивать принятое судом первой инстанции решение по уголовному делу, поэтому следует изготовить его перевод в случаях:

- если производство велось на государственном языке одной из национальных республик, 
- если хотя бы один из подсудимых или потерпевших не владел языком судопроизводства.

Наличие перевода протокола судебного заседания будет являться одной из гарантий качества работы переводчика. При возникновении спора о правильности перевода возможно будет провести лингвистическую экспертизу. Письменный перевод протокола судебного заседания должен изготовить переводчик, который принимал участие при ознакомлении с ним.

\section{Литература:}

1. Аскерова Ф.Ф.к. Отдельные вопросы участия переводчика в уголовном процессе по УПК Российской Федерации и УПК Азербайджанской Республики (сравнительная характеристика) // Вестник Удмуртского унта. Серия «Экономика и право» - 2015, № 3 - С. 86-89.

2. Ишмухаметов Я.М. Язык судопроизводства как принцип российского уголовного процесса: Автореф. дис. ... канд. юрид. наук. Ижевск, 2006 $24 \mathrm{c}$.

3. Татьянина Л.Г. Реализация принципа «язык уголовного судопроизводства» в досудебных стадиях процесса // Конституция Российской Федерации как гарант прав и свобод человека и гражданина при расследовании преступлений : материалы Междунар. науч.-практ. конф., (Москва, 14 ноября 2013 г.): в 3 ч. / под ред. А. И. Бастрыкина. - Москва, 2013. - Ч. 3. C. 209-212. 